Article

\title{
Experimental Analysis of Brewers' Spent Grains Steam Gasification in an Allothermal Batch Reactor
}

\author{
Sérgio Ferreira ${ }^{1}$, Eliseu Monteiro ${ }^{2,3, *}$ (D) , Paulo Brito ${ }^{2}{ }^{-}$, Carlos Castro ${ }^{1}$, Luís Calado ${ }^{2}$ \\ and Cândida Vilarinho ${ }^{1}$ \\ 1 CT2M-Centre for Mechanical and Materials Technologies, Mechanical Engineering Department of Minho \\ University, 4804-533 Guimarães, Portugal; sergio.c.m.ferreira@gmail.com (S.F.); ccosta@cvresiduos.pt (C.C.); \\ candida@dem.uminho.pt (C.V.) \\ 2 VALORIZA-Research Center for Endogenous Resource Valorisation, Polytechnic Institute of Portalegre, \\ 7300-555 Portalegre, Portugal; pbrito@ipportalegre.pt (P.B.); luis.calado@ipportalegre.pt (L.C.) \\ 3 CIENER-LAETA/Faculty of Engineering, University of Porto, 4200-465 Porto, Portugal \\ * Correspondence: eliseu@ipportalegre.pt or elmmonteiro@portugalmail.pt; Tel.: +351-254-300-200
}

Received: 28 January 2019; Accepted: 5 March 2019; Published: 8 March 2019

\begin{abstract}
In this work, brewers' spent grains (BSG) were evaluated and studied in order to obtain a combustible gas by means of allothermal steam gasification. BSG were preprocessed in a rotary dryer and a pelletizer prior to gasification in an indirectly heated batch reactor. BSG characterization was conducted by means of proximate, ultimate, and thermogravimetric analysis, allowing us to conclude that BSG have characteristics comparable to those of regular lignocellulosic biomasses. Gasification tests were performed in an allothermal bench-scale batch reactor in order to determine the effect of temperature and steam-to-biomass ratio (S/B) in the produced gas. The produced gas was mainly composed of $22.8-30.2 \% \mathrm{H}_{2}, 15.1-22.3 \% \mathrm{CO}$, and $7.2-11.1 \% \mathrm{CH}_{4}$, contributing to a heating value of $8.11-9.0 \mathrm{MJ} / \mathrm{Nm}^{3}$ with the higher values found for a low $\mathrm{S} / \mathrm{B}$ ratio and for high temperatures. The performance of the process was assessed by evaluating the cold gas and carbon conversion efficiencies. These indicators were found to be in the ranges $47.0 \%-52.1 \%$ and $57.0 \%-62.7 \%$, respectively. The main conclusion of this work is that the produced gas obtained from BSG steam gasification has sufficient quality to open other options to beer producers to use their own brewing wastes to satisfy their energy needs, allowing them to progress toward the circular economy concept.
\end{abstract}

Keywords: brewers' spent grains; allothermal gasification; batch reactor

\section{Introduction}

Faster industry is required by contemporary consumers, which can lead to high power consumption and the production of large amounts of wastes [1]. The electricity consumption of a company can equate to up to $10 \%$ of its net income. One way in which industries become more efficient is by using their own by-products and wastes to produce their own energy. With this approach, a company can move closer to the circular economy concept [2].

A brief analysis of a Portuguese scenario highlights the brewing industry, which represents about $1 \%$ of the gross domestic product-a relevant weight in the country's economy. This sector in Portugal produces about 160 thousand tonnes of waste per year, most notably brewers' spent grains (BSG), which represent about $85 \%$ of these wastes [3,4]. Therefore, about 135,000 tonnes of BSG are produced per year in Portugal as a by-product of the beer production process.

The beer-brewing process is energy intensive, utilizing large amounts of heat and electricity. Primary energy sources of fossil fuels are mostly used, and Portugal is dependent to a great extent 
on imports of these [5]. In this sector, a number of wastes and by-products are produced, including BSG, Trub hot (insoluble hop residue), and yeast residues [6]. The use of the most representative by-products of beer production has been researched and applied to optimize the environmental and economic sustainability of this market [7]. Some authors report that more than 3 million tonnes of BSG are produced in the EU per year [8,9]. BSG are a residual by-product of ensuring proper extraction of the must [10]. It is estimated that for every 100 litters of beer brewed, about $20 \mathrm{~kg}$ of BSG are produced [11]. Another well-known characteristic of BSG is that they deteriorate quickly-within a day or two after production.

All brewers face the problem of how to handle the BSG. The larger the brewery, the more options are available. Currently, the three most common solutions for dealing with BSG in national breweries are producing animal feed, offering it to local farmers, or sending it to a landfill. The latter is less desirable because of the costs incurred by brewers and due to environmental problems.

In recent years, BSG have received more attention as a marketable commodity since they are now increasingly expensive to dispose of. In addition, BSG represent an increasing environmental problem, so more options have been studied: as a source of healthy nutrients providing protection for cardiovascular diseases and cancer through arabinoxylans derived from BSG [12] and through BSG-enriched biscuits [13]; as construction material using BSG as an additive in the production of building bricks [14] providing higher strength, higher porosity, and a lower density, which give them better properties of thermal insulation than those produced from a similar production clay; and as biomass for biogas production through anaerobic digestion, reported as an application especially appropriate for BSG due to their high moisture content $[15,16]$. However, biogas production from BSG is repressed by intermediate lignocellulosic biodegradation products $[15,16]$. This inhibition is not prevented even by submitting BSG to mechanical, thermochemical, or chemical pretreatments $[15,16]$. Therefore, according to Mussato [3], biogas production from BSG needs further developments in order to achieve stable production; this is beyond the scope of the present work.

Another alternative for BSG reuse is thermochemical conversion, since the chemical composition of BSG indicates high energy potential to be exploited by recovery techniques [17]. Conventional gasification [18-23] and plasma gasification [24,25] are some of these thermochemical techniques with high potential to produce alternative fuels from both efficiency and economic perspectives [26]. It is considered an important route to convert biomass and waste materials to useful gas products that can be converted into energy via several technological options [27]. Gasification's environmental performance is considered one of the greatest strengths of this technology, with this technology being identified as a possible solution to meet the increasingly strict environmental regulations applied around the world [28].

A review of the literature allows us to conclude that there have been only a few studies that have explored the pyrolysis and gasification of BSG. Okmoto et al. [29] investigated the possibility of BSG conversion into gas in a laboratory-scale batch reactor using a nickel catalyst at $623 \mathrm{~K}$ and $18 \mathrm{MPa}$. They obtained a gas yield of approximately $85 \%$ on a carbon basis. They concluded that the conversion of brewers' spent grains to gas is a good manner of producing energy with few environmental problems. Mahmood et al. [30] used a bench-scale batch pyrolysis reactor to pyrolyze small samples of BSG. A reforming nickel catalyst was added downstream of the reactor for cracking and reforming of the pyrolysis products with and without the addition of steam. The obtained results indicated that catalytic reforming promotes an increase in $\mathrm{CO}$ and $\mathrm{H}_{2}$ contents. The process also showed an increase in heating value for the produced gas ranging between 10.8 and $25.2 \mathrm{MJ} / \mathrm{m}^{3}$ as the reforming temperature increased. Borel et al. [31] studied the physicochemical properties, the thermal degradation behavior, and the products generated from pyrolysis of BSG to evaluate the potential for bio-oil production via pyrolysis. Thermogravimetric analyses were performed in a nitrogen atmosphere. The results showed that the BSG displayed good potential for bio-oil production owing to their high volatile matter content and high heating value. 
This brief literature review allows us to verify that studies on the thermochemical conversion of brewers' spent grains, especially on the gasification process, are actually very rare. This was the spark for us to experimentally investigate the steam gasification of brewers' spent grains in an allothermal batch reactor to evaluate the potential of this agro-industrial residue for energy production.

\section{Materials and Methods}

\subsection{Materials}

The raw material used in this work was supplied by a Portuguese brewer producer and immediately collected after being separated from the wort. It was transported on the same day to avoid BSG degradation. BSG contain large amounts of moisture, usually between $67 \%$ and $81 \%$. That characteristic and its fermentable sugar content make storage and transportation difficult since BSG deteriorate rapidly due to microbial activity [32]. In this work, BSG pretreatment was performed in two steps: drying and densification. After these two preprocessing steps, the resulting BSG pellets were subjected to steam gasification in an allothermal batch reactor.

\subsection{Preprocessing Apparatus}

The reduction of the BSG moisture content was performed in the rotary dryer shown in Figure 1.

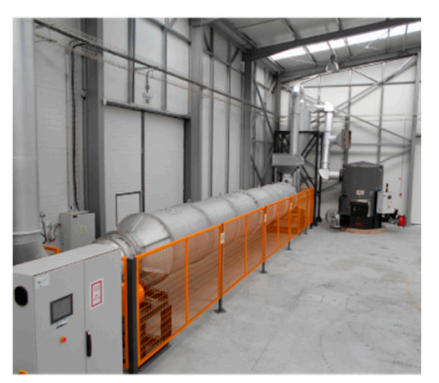

Figure 1. Rotary dryer experimental apparatus.

The rotary dryer used in this study was $9.955 \mathrm{~m}$ long and $1.166 \mathrm{~m}$ wide with a rotation speed of 30 $\mathrm{rpm}$. A biomass boiler provides hot flue gases at around $300^{\circ} \mathrm{C}$ for the rotary dryer, which has a drying capacity of $300 \mathrm{~kg} / \mathrm{h}$. This device allowed us to reduce the BSG moisture from $78.8 \%$ as-received to a moisture content of around $15 \%$.

The densification process of the dried BSG was performed in a Kahl AK07 pelleting press with a power of $3 \mathrm{~kW}$ and a capacity of $10-50 \mathrm{~kg} / \mathrm{h}$, as shown in Figure 2.

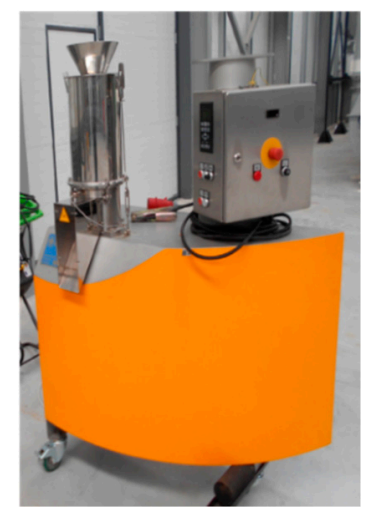

Figure 2. The pelleting press.

This pelleting press was of a flat die type, falling in the category of roll extruders. The operating principle of flat die presses lies in forcing a biomass product through a flat die plate with orifices 
of a defined diameter by means of a rotating roller. The resulting extrudates are then cut with a simultaneously rotating knife to the chosen length. The pellets produced were cylindrical, $6 \mathrm{~mm}$ in diameter, and around $15 \mathrm{~mm}$ in length.

\subsection{Gasification Experimental Apparatus}

The equipment used for this project was a pilot unit that was built in Minho University to perform several assays considering different variables: materials, temperature ranges, and thermochemical processes (torrefaction, carbonization, pyrolysis, and gasification).

This reactor was a lab-scale batch gasifier of $35 \mathrm{~L}$ in volume, heated by three $2.5 \mathrm{~kW}$ resistors. A scheme of the gasification experimental apparatus is shown in Figure 3.

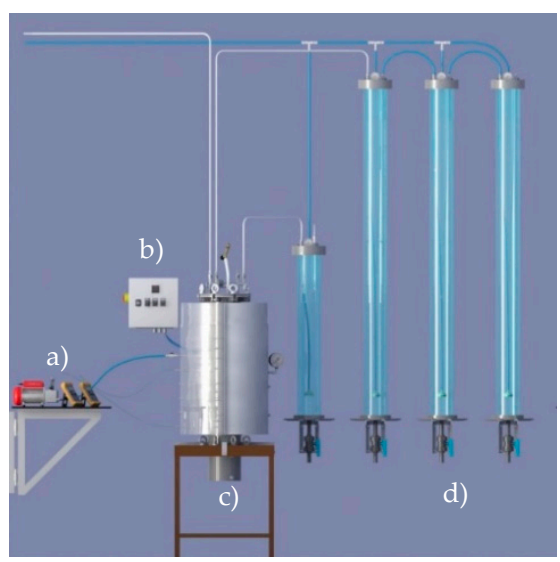

Figure 3. Gasification experimental apparatus: (a) vacuum pump, (b) control panel, (c) reactor, (d) and wet scrubber.

The reactor was discontinuous, which means that material neither enters nor exits during the reaction; it is only supplied before the test is started following a specified heating rate and allowed to react for a predetermined duration (residence time). This lab-scale batch gasifier, developed for the gasification of biomass, consisted of an allothermal reactor operating at variable pressure of $0.3-1.5 \mathrm{bar}$ and temperatures up to $900^{\circ} \mathrm{C}$.

The injection of oxidizing agent into the reactor was done by a peristaltic pump with a minimum impulse of $16 \mathrm{~s}$.

The produced gas exited the reactor and was cleaned and cooled in a wet scrubber containing $10 \mathrm{~L}$ of water. The cooled and cleaned produced gas was collected by a $1.0 \mathrm{~m}^{3}$ storage bag from which produced gas samples were taken for chromatography analysis.

The gasification tests were carried out at variable pressure that was achieved in the reactor by the reactions taking place at temperatures of $750{ }^{\circ} \mathrm{C}, 800^{\circ} \mathrm{C}$, and $850^{\circ} \mathrm{C}$, for steam-to-biomass ratios of 0.5 , 0.735 , and 1.0.

The steam-to-biomass ratio was calculated as the ratio between the water added to the reactor and the biomass input.

\subsection{Ultimate Analysis}

The chemical composition of BSG in terms of carbon, hydrogen, nitrogen, sulphur, and oxygen was determined using a CHNS-O Thermo Flash 2000 elemental analyzer, operating at $900{ }^{\circ} \mathrm{C}$ in an atmosphere of pure oxygen. The oxygen content was calculated by difference on a dry and ash-free basis according to Equation (1):

$$
O(\%)=100-C(\%)-H(\%)-N(\%)-S(\%) .
$$




\subsection{Proximate Analysis}

Ash, volatile matter (VM), and moisture (M) contents were measured according to the ISO standards ISO 18122:2015, ISO 18123:2015, and ISO 18134-1:2015, respectively. The fixed carbon (FC) was determined by difference according to Equation (2) [33].

$$
F C(\%)=100-\mathrm{M}(\%)-\mathrm{VM}(\%)-\mathrm{Ash}(\%)
$$

\subsection{Calorific Value}

The higher heating value (HHV) of BSG was quantified using an oxygen bomb calorimeter (IKA C2000). The measurements were performed in triplicate according to ASTM D2015 and compared with the correlation of Channiwala and Parikh [34] expressed in Equation (3):

$$
H H V_{b i o}=349.1 C+1178.3 H+100.5 S-103.4 O-15.1 \mathrm{~N}-21.1 \mathrm{Ash}\left(\frac{\mathrm{kJ}}{\mathrm{kg}}\right)
$$

where the mass percentages of the compounds are those obtained by ultimate analysis on a dry basis. The lower heating value ( $L H V)$ of the biomass was estimated based on Equation (4) [35]:

$$
L H V_{b i o}=H H V_{b i o}-2260(0.09 H+0.01 M)\left(\frac{k J}{k g}\right)
$$

where $L H V, H H V, H$, and $M$ denote the lower heating value, higher heating value, hydrogen percentage, and moisture percentage, respectively, on an as-received basis. The value 2260 is the latent heat of steam in $\mathrm{kJ} / \mathrm{kg}$.

The lower heating value of the dry gas was estimated based on the relative molar fraction $(Y)$ of the fuel gas components' present and respective $L H V$ values at reference conditions for those fuel gas components [36]:

$$
L H V_{g a s}=10.79 Y_{\mathrm{H}_{2}}+12.62 Y_{\mathrm{CO}}+35.81 Y_{\mathrm{CH}_{4}} .
$$

\subsection{Thermogravimetric Analysis (TGA)}

Apart from ultimate and proximate analysis, it is possible to characterize a biomass by pyrolysis of a small sample in an inert gas stream or by combustion in an oxygen atmosphere. Thermogravimetric analysis in air yields the burning profile and a mass loss trace. The first derivative of the weight loss curve gives the characteristic temperatures for moisture loss, volatile loss, volatile ignition, char ignition, and char burn-out.

In differential thermal analysis (DTA), the temperature differential between the sample and an inert reference is plotted, giving a more sensitive indication of the reaction kinetics taking place. The peak of the derivative curve indicates the point of the greatest rate of change on the mass loss curve.

A thermogravimetric analyzer (PerkinElmer STA6000) was used for monitoring the mass loss (TG) and the differential weight loss (DTG) profiles. The thermogravimetric tests of the BSG samples (24 mg) were performed from 30 to $900{ }^{\circ} \mathrm{C}$ at a heating rate of $10^{\circ} \mathrm{C} / \mathrm{min}$, using nitrogen as the purge gas at a flow rate of $50 \mathrm{~mL} / \mathrm{min}$.

\subsection{Gas Chromatography}

The collected gas samples were analyzed by gas chromatography using a Chrompack CP 9001 Gas Chromatograph with thermal conductivity detection and a Porapack Q \& Molsieve 5 Å column (Varian $2 \mathrm{~m} \times 1 / 8^{\prime \prime} \times 2 \mathrm{~mm} \mathrm{SS}, 80-100 \mathrm{mesh}$ ).

\subsection{Process Efficiencies}

The performance parameters of a gasification process include the carbon conversion efficiency (CCE) and the cold gas efficiency (CGE). 
The cold gas efficiency correlates the chemical enthalpy of the produced gas to the thermal biomass input on an LHV basis and can be calculated for an allothermal process as follows:

$$
C G E=\frac{\dot{m}_{\text {gas }} \times L H V_{\text {gas }}}{\dot{m}_{\text {bio }} \times L H V_{\text {bio }}+\text { Heat }}
$$

where $\dot{m}$ denotes the mass flow and Heat is the electrical energy supplied to the reactor.

The carbon conversion efficiency defines the fraction of carbon from BSG converted to carbon in the producer gas stream. It gives an indication of the amount of unconverted carbon and provides a measure of the chemical efficiency of the process. It can be calculated as follows [37]:

$$
C C E=\frac{12 \times M}{X_{c} \times m}
$$

where $M$ denotes the total moles of carbon in the producer gas stream, $X_{C}$ is the carbon fraction in the BSG, and $m$ is the BSG mass input to the gasifier.

\section{Results and Discussion}

\subsection{Biomass Characterization}

The BSG used in the gasification experiments were characterized in this work in terms of relevant properties for the gasification process (proximate and ultimate analysis and heating value). The results of the BSG characterization and the standard methods used are shown in Table 1.

Table 1. Characterization of the brewers' spent grains (BSG) and the standard methods used.

\begin{tabular}{lcl}
\hline Parameter & Value & Standard Method \\
\hline Moisture $(\%)$ & $\begin{array}{c}78.8 \% \text { (as-received); 15\% (after } \\
\text { drying); } 1.7 \% \text { (after densification) } \\
148 \text { (after drying); } 517 \text { (after } \\
\text { densification) }\end{array}$ & ISO 18134-1:2015 \\
Density $\left(\mathrm{kg} / \mathrm{m}^{3}\right)$ & 3.8 & ISO 12154:2014 \\
Proximate analysis (\%, d.b.) & 86.8 & ISO 18122:2015 \\
Ash & 9.4 & ISO 18123:2015 \\
Volatile & & \\
Fixed carbon & 48.3 & ISO 16948:2015 \\
Ultimate analysis (\%, daf) & 5.6 & ISO 16948:2015 \\
$\mathrm{C}$ & 5.5 & ISO 16948:2015 \\
$\mathrm{H}$ & 1.9 & ISO 16994:2016 \\
$\mathrm{N}$ & 38.7 & Calculated using Equation (1) \\
$\mathrm{S}$ & 17.8 & ASTM D2015 \\
$\mathrm{O}$ & 16.5 & Calculated using Equation (4) \\
$\mathrm{HHV}(\mathrm{MJ} / \mathrm{kg})$ & & \\
$\mathrm{LHV}(\mathrm{MJ} / \mathrm{kg})$ & &
\end{tabular}

\subsection{Van Krevelen Diagram}

Van Krevelen diagrams plot the hydrogen-to-carbon atomic ratio as a function of the oxygen-to-carbon atomic ratio of carbon compounds on a dry and ash-free basis. The principle of a van Krevelen diagram is that the carbon compounds (e.g., biomass, coal, etc.) that fall within a group will have similar properties [38]. Thus, the van Krevelen diagram seems to be an appropriate method to highlight compositional differences within and between carbon compounds. Figure 4 shows a wide variety of biomasses in a van Krevelen diagram to obtain a comparison of the BSG with other lignocellulosic biomasses. 


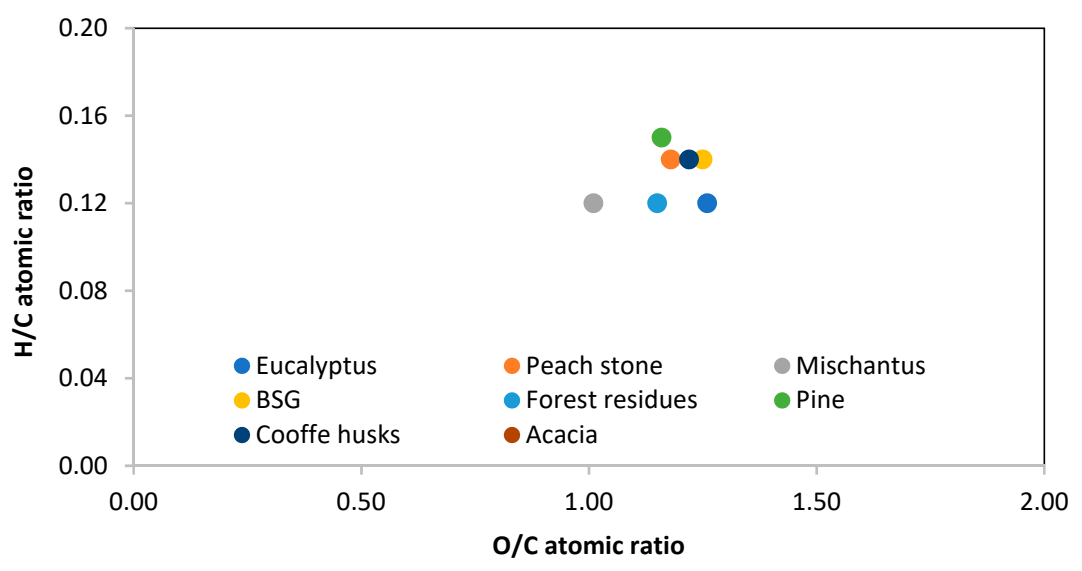

Figure 4. Van Krevelen diagram for various biomasses.

Figure 4 allows us to conclude that BSG are perfectly integrated within the group of lignocellulosic biomasses with an $\mathrm{H} / \mathrm{C}$ ratio of 0.14 and an $\mathrm{O} / \mathrm{C}$ ratio of 1.25 . Therefore, according to the Van Krevelen diagram, BSG have good thermal properties when compared with other biomass materials such as forest residues [39], eucalyptus [40], coffee husks [41], peach stone [42], and miscanthus [43]. These results of the chemical analysis of BSG are consistent with values reported in the literature $[30,44,45]$.

\subsection{Thermogravimetric Analysis (TGA)}

The thermogravimetric and differential thermal analysis profiles of BSG are shown in Figure 5.

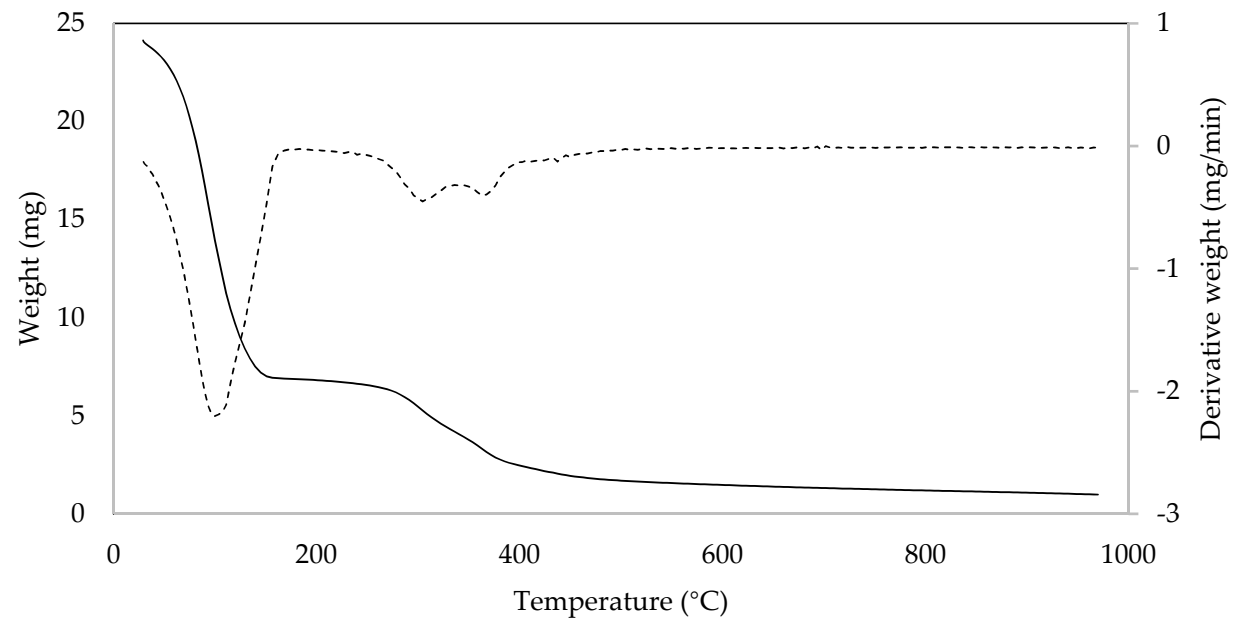

Figure 5. Thermogravimetric profile of brewers' spent grains (the continuous line represents the TG curve while the dashed line represents the DT curve).

Much of the mass loss for BSG occurs at about $100{ }^{\circ} \mathrm{C}$ with moisture release. The elevated moisture content of the BSG is the main reason for this behavior.

The mass loss curve produced between 200 and $500{ }^{\circ} \mathrm{C}$ shows a gradual loss due to pyrolysis of the lignocellulosic material, which is attributed to the decomposition (volatile loss) of the macromolecular components hemicellulose, cellulose, and lignin in agreement with the temperature ranges of decomposition reported in the literature [46]. After this, only carbon and ash remain, and an oxidizer is needed to burn the carbon. The DTG profile for BSG shows a first peak at $100{ }^{\circ} \mathrm{C}$ which corresponds to the release of moisture. At $300{ }^{\circ} \mathrm{C}$, a second peak is observed, related to the decomposition of the hemicellulose and the initial decomposition of the cellulose. The third peak observed at $360{ }^{\circ} \mathrm{C}$ is 
related to the final decomposition of cellulose and lignin. The high content of volatiles causes the release of the majority of volatiles below $400{ }^{\circ} \mathrm{C}$.

\subsection{Allothermal Gasification}

The operating conditions of the allothermal gasifier were characterized by the biomass input, steam-to-biomass ratio (S/B), gasifier temperature, and produced gas composition. Table 2 shows information about the gasifier operating conditions and liquid, solid, and gas fractions of the produced gas. The measurements were performed in triplicate and the uncertainties are included in Table 2.

Table 2. Results of the gas measurements.

\begin{tabular}{lccccccccc}
\hline Temperature $\left({ }^{\circ} \mathrm{C}\right)$ & 750 & 750 & 750 & 800 & 800 & 800 & 850 & 850 & 850 \\
\hline S/B ratio $(\mathrm{g} / \mathrm{g})$ & 0.5 & 0.735 & 1.0 & 0.5 & 0.735 & 1.0 & 0.5 & 0.735 & 1.0 \\
\hline Biomass input $(\mathrm{g})$ & $500 \pm 1$ & $500 \pm 1$ & $500 \pm 1$ & $500 \pm 1$ & $500 \pm 1$ & $500 \pm 1$ & $500 \pm 1$ & $500 \pm 1$ & $500 \pm 1$ \\
\hline Steam input $(\mathrm{mL})$ & $250 \pm 1$ & $367.5 \pm 1$ & $500.4 \pm 1$ & $250 \pm 1$ & $367.5 \pm 1$ & $500 \pm 1$ & $250 \pm 1$ & $367.5 \pm 1$ & $500 \pm 1$ \\
\hline $\mathrm{H}_{2}$ & $22.8 \pm 0.6$ & $24.6 \pm 1.9$ & $25.3 \pm 0.4$ & $23.9 \pm 0.1$ & $24.9 \pm 0.4$ & $26.6 \pm 0.9$ & $27.8 \pm 0.3$ & $28.4 \pm 1.5$ & $30.2 \pm 2.8$ \\
\hline $\mathrm{CO}$ & $18.5 \pm 0.3$ & $15.4 \pm 0.5$ & $15.1 \pm 0.2$ & $20.2 \pm 0.1$ & $17.1 \pm 0.1$ & $15.5 \pm 0.4$ & $22.3 \pm 0.4$ & $20.4 \pm 0.6$ & $19.6 \pm 2.0$ \\
\hline $\mathrm{CO} 2$ & $17.6 \pm 0.3$ & $20.1 \pm 0.2$ & $21.6 \pm 0.5$ & $15.4 \pm 0.4$ & $16.7 \pm 0.1$ & $20.1 \pm 0.4$ & $15.1 \pm 0.3$ & $15.7 \pm 0.9$ & $16.1 \pm 1.6$ \\
\hline $\mathrm{CH}_{4}$ & $11.1 \pm 0.2$ & $10.2 \pm 0.2$ & $9.7 \pm 0.2$ & $10.5 \pm 0.2$ & $10.0 \pm 0.6$ & $9.4 \pm 0.2$ & $8.9 \pm 0.3$ & $8.1 \pm 0.6$ & $7.2 \pm 1.1$ \\
\hline Tars $\left(\mathrm{g} / \mathrm{Nm}^{3}\right)$ & $3.0 \pm 0.9$ & $5.1 \pm 0.4$ & $5.8 \pm 0.5$ & $5.2 \pm 0.2$ & $7.1 \pm 0.6$ & $9.1 \pm 0.3$ & $9.7 \pm 0.4$ & $10.0 \pm 0.3$ & $10.1 \pm 0.4$ \\
\hline Ash $+\mathrm{char}(\mathrm{g})$ & $123 \pm 4$ & $115 \pm 6$ & $109 \pm 5$ & $117 \pm 4$ & $114 \pm 7$ & $108 \pm 6$ & $116 \pm 8$ & $105 \pm 6$ & $94 \pm 9$ \\
\hline $\mathrm{LHV}\left(\mathrm{MJ} / \mathrm{Nm}{ }^{3}\right)$ & 8.77 & 8.25 & 8.11 & 8.89 & 8.43 & 8.14 & 9.00 & 8.54 & 8.31 \\
\hline $\mathrm{CCE}(\%)$ & 62.7 & 60.7 & 61.6 & 61.2 & 58.2 & 59.8 & 61.5 & 58.7 & 57.0 \\
\hline $\mathrm{CGE}(\%)$ & 50.8 & 47.8 & 47.0 & 51.5 & 48.8 & 47.1 & 52.1 & 49.4 & 48.1 \\
\hline
\end{tabular}

The LHV of the dry gas was found to be between 7.75 and $9.09 \mathrm{MJ} / \mathrm{Nm}^{3}$, with the higher values found for low S/B ratios and high temperatures. The CGE of the dry gas was found to be between $47.0 \%$ and $52.1 \%$. The CCE of the dry gas was found to be between $57.0 \%$ and $62.7 \%$, reflecting an important presence of char in the ashes, as shown in Table 2.

\subsubsection{Effect of the Temperature on Gasification}

The reactor temperature is one of the most important operating variables for gasification, because the main gasification reactions are endothermic. The final gas composition of the gasification process is the result of combining a series of complex and competing chemical reactions. Figure 6 depicts the syngas molar fraction as a function of the gasification temperature.

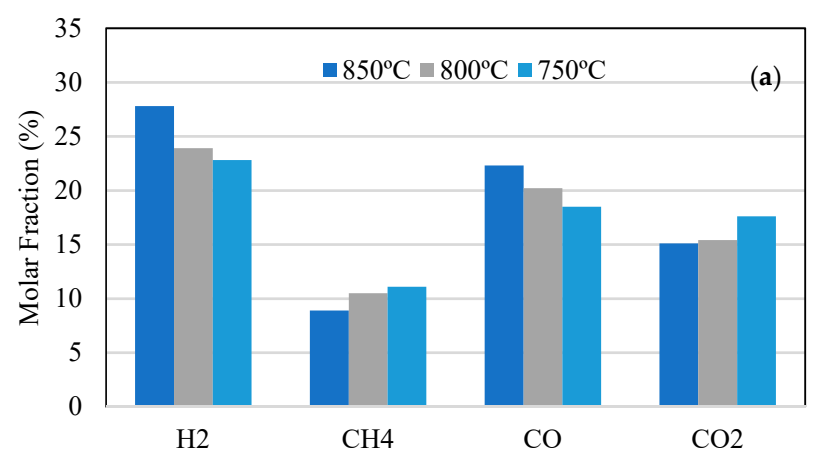

Figure 6. Cont. 

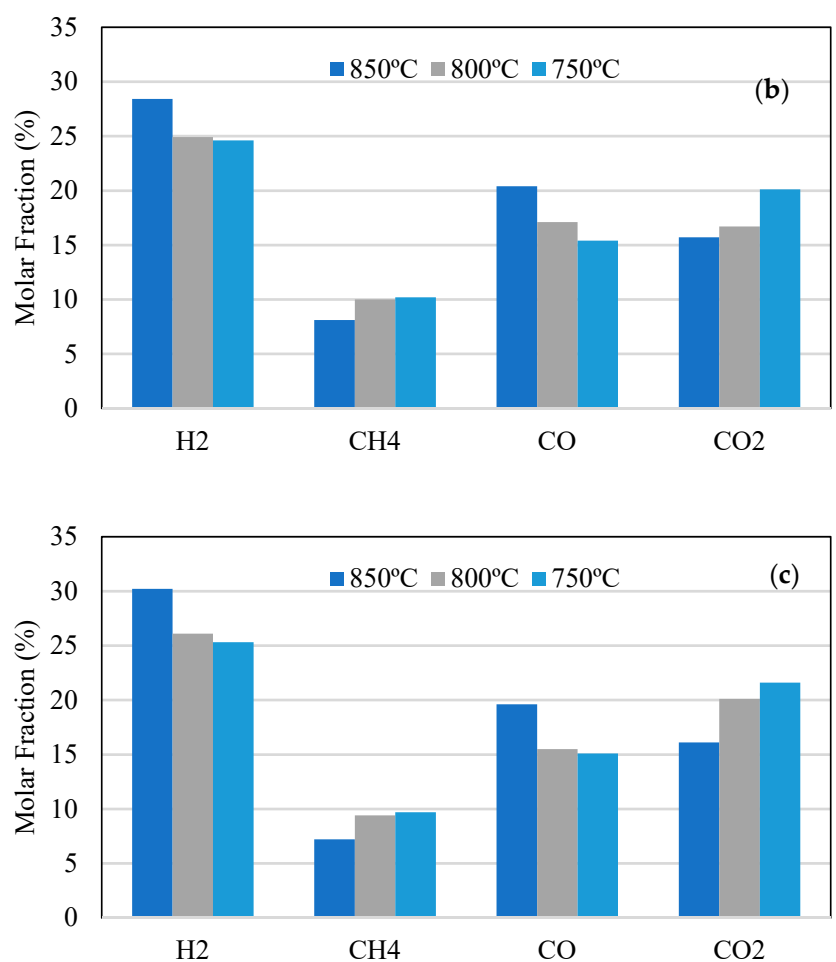

Figure 6. Effect of the temperature on the produced gas for S/B ratios of (a) 0.5, (b) 0.735, and (c) 1.0.

The main gasification reactions (Boudouard reaction, water-gas, and water-gas shift reactions) are endothermic, which are strengthened with increasing temperature according to Le Chatelier's principle. Therefore, the content of $\mathrm{H}_{2}$ increased with the temperature, while that of $\mathrm{CH}_{4}$ decreased.

The content of $\mathrm{CO}$ increased, which can be due to the enhanced Boudouard reaction, carbon partial oxidation, and water-gas reaction.

On the other hand, the content of $\mathrm{CO}_{2}$ decreased in the same temperature range. Various authors have reported a similar trend observing a decrease of $\mathrm{CO}_{2}$ content with temperature for the gasification of other biomasses and wastes [36,43]. The suggested reason is that $\mathrm{CO}_{2}$ is consumed by the Boudouard and tar-reforming reactions. In addition, at elevated temperature in the gasifier, the exothermic water-gas shift reaction is shifted to the $\mathrm{H}_{2} \mathrm{O}$ and $\mathrm{CO}$ side, which lowered the yield of $\mathrm{CO}_{2}$.

\subsubsection{Effect of the Steam-to-Biomass Ratio on Gasification}

The steam-to-biomass ratio (S/B) is defined as the relation between the steam flow rate and the biomass flow rate fed into the gasifier and is a key process parameter involved in steam gasification. The effect of S/B on gas composition is shown in Figure 7.

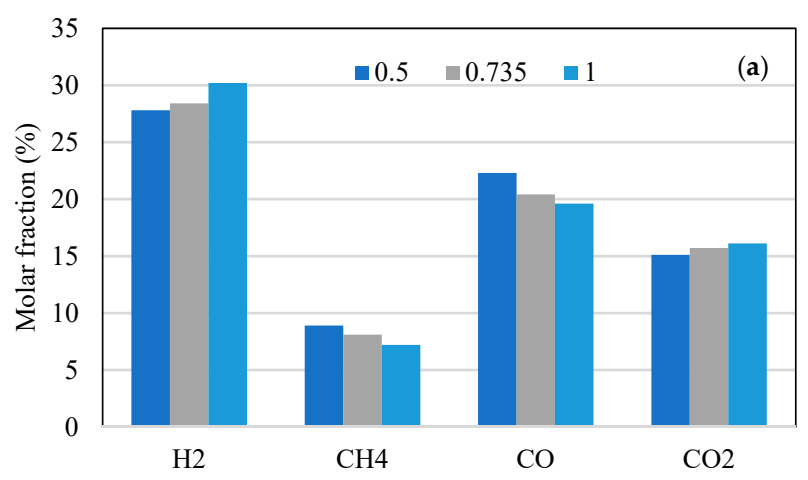

Figure 7. Cont. 

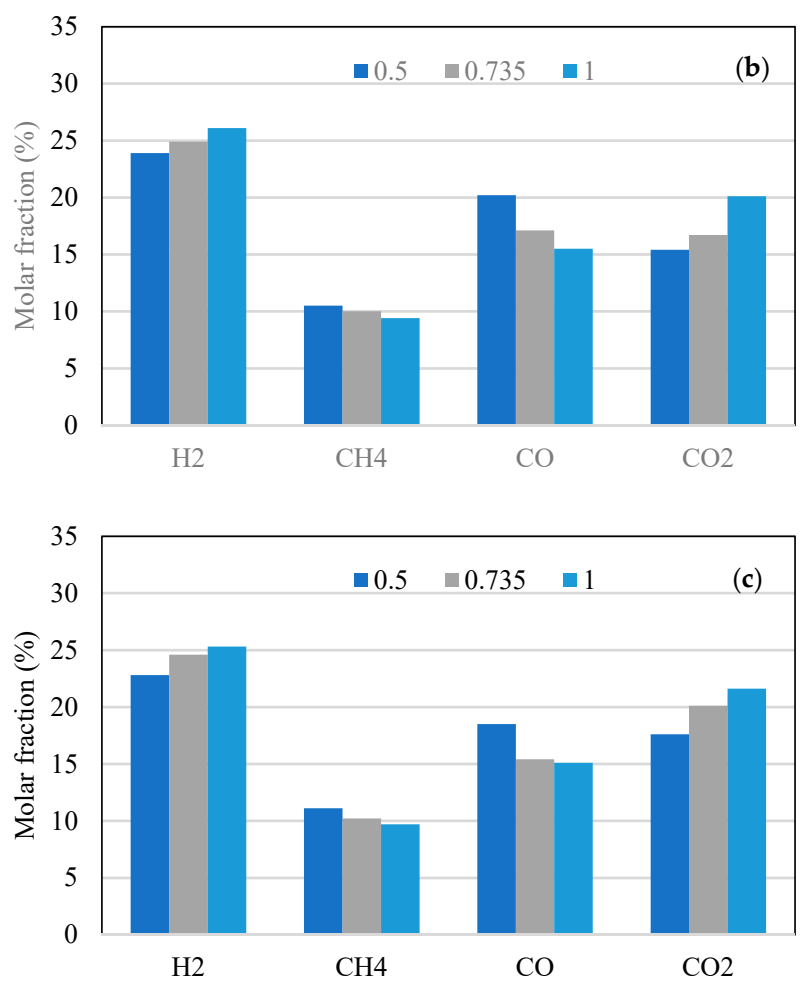

Figure 7. Effect of the steam-to-biomass ratio on the produced gas for temperatures of (a) $850{ }^{\circ} \mathrm{C},(\mathbf{b})$ $800{ }^{\circ} \mathrm{C}$, and (c) $750{ }^{\circ} \mathrm{C}$.

The decrease in $\mathrm{CO}$ content, associated with the increase of $\mathrm{H}_{2}$ and $\mathrm{CO}_{2}$ for higher $\mathrm{S} / \mathrm{B}$ ratios, is explained by the raised partial pressure inside the reactor promoted by water vaporization, as stated by other researchers $[47,48]$. The steam injection favors the water-gas, water-gas shift, and steam-reforming reactions which, besides the described effects, also enhance hydrocarbon breakdown. The $\mathrm{CO}_{2}$ contents show a tendency to increase with increasing $\mathrm{S} / \mathrm{B}$ ratios, which can be attributed to the effect of oxidation reactions.

\subsubsection{Effect of the Process Parameters on the LHV}

Figure 8 presents the lower heating value of the produced gas as a function of $\mathrm{S} / \mathrm{B}$ and temperature calculated according to Equation (1).

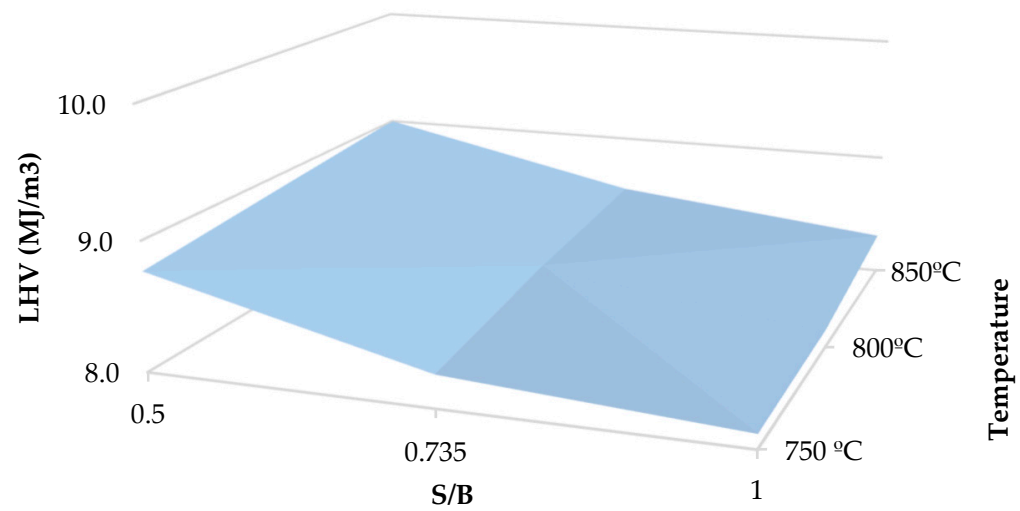

Figure 8. Effect of the steam-to-biomass ratio and temperature on the LHV of the produced gas.

The LHV is seen to decrease with S/B due to the decrease in the $\mathrm{CO}$ and $\mathrm{CH}_{4}$ contents in the producer gas besides the increase in the hydrogen amount. On the other hand, the LHV of the produced gas increases with temperature, essentially due to the increase in $\mathrm{CO}$ and $\mathrm{H}_{2}$. 


\subsubsection{Effect of the Process Parameters on Tar Yields}

Tars are mostly heavy hydrocarbons formed in the pyrolysis step in the gasification process. Tars can condense at low temperature, resulting in blockage in the process equipment and leading to decreased performance and increased maintenance. Figure 9 shows tar yields as a function of S/B and temperature.

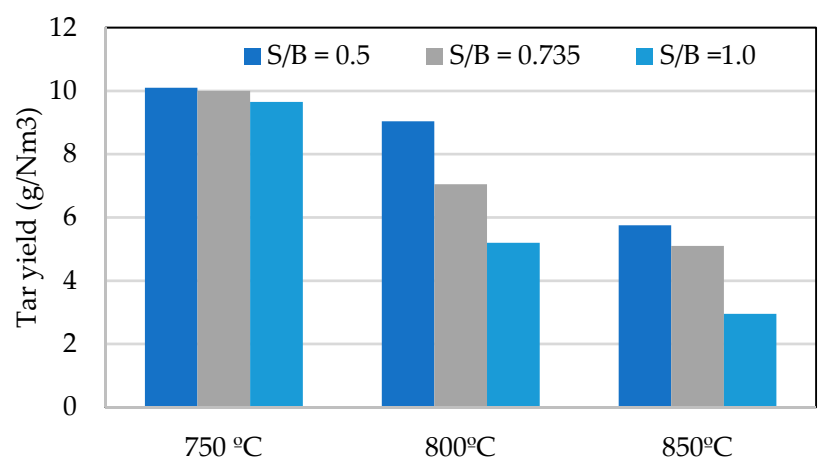

Figure 9. Effect of the temperature and S/B ratio on tar yields.

The increase of the S/B ratio promotes decreased tar content, which is attributed to steam reforming of the tar [48]. High temperature favors destruction and reforming of tar, leading to a decrease in tar content [48]. Tar yields obtained by steam gasification of BSG in this work are not dissimilar from those obtained from other biomasses [49]. Nevertheless, it would require cleaning before it can be used on downstream equipment since it is beyond the general acceptable limits [49].

\subsubsection{Effect of the Process Parameters on Efficiencies}

Figure 10 describes the effect of gasification temperature as well as S/B ratio on CCE and CGE.

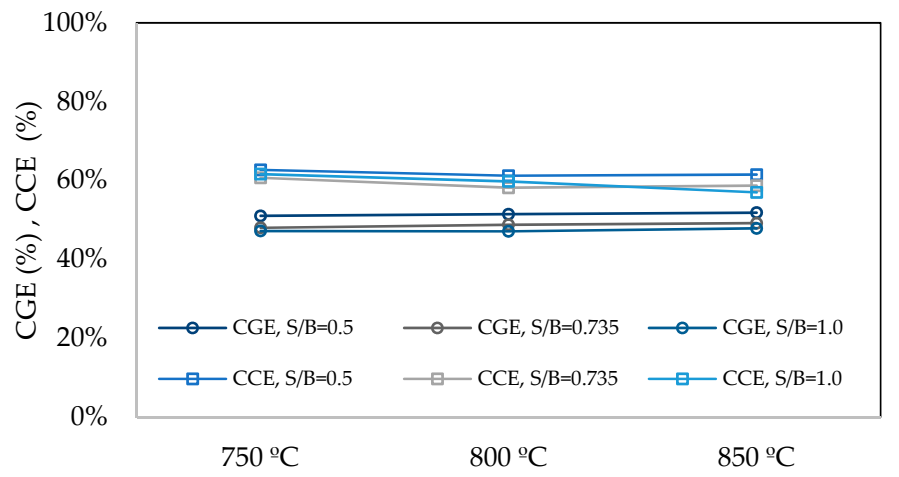

Figure 10. Effect of the temperature and S/B ratio on CCE and CGE.

Slight variation of the efficiencies can be seen from Figure 10 in the range of process parameters studied. However, higher temperature slightly increases cold gas efficiency essentially due to the increased $\mathrm{CO}$ and $\mathrm{H}_{2}$ content in the produced gas [48]. The carbon conversion efficiency slightly decreases with the temperature, essentially due to the reduction of the $\mathrm{CH}_{4}$ content, which is not compensated by the increased CO content of the produced gas.

\section{Conclusions}

In the current reported work, brewers' spent grains were pre-processed by way of drying and pelletization and then subjected to steam gasification in an allothermal batch reactor. 
The drying process allowed us to reduce the moisture content of BSG from $78.8 \%$ to $15 \%$. The palletization process allowed us to increase the BSG density from $148 \mathrm{~kg} / \mathrm{m}^{3}$ to $517 \mathrm{~kg} / \mathrm{m}^{3}$ and further reduce the moisture content to $12.7 \%$.

BSG characterization through proximate, ultimate, and thermogravimetric analysis and a van Krevelen diagram allowed us to conclude that BSG have characteristics comparable to those of regular lignocellulosic biomasses.

Steam gasification of BSG was carried out to determine the effect of steam-to-biomass ratio and temperature on the produced gas composition. We found that $\mathrm{CO}$ and $\mathrm{CH}_{4}$ contents decrease with $\mathrm{S} / \mathrm{B}$, while $\mathrm{H}_{2}$ and $\mathrm{CO}_{2}$ contents increase. This behavior leads to a decrease in the LHV of the produced gas with S/B. Regarding the effect of the temperature, it was observed that $\mathrm{CO}$ and $\mathrm{H}_{2}$ contents increase with temperature, while $\mathrm{CH}_{4}$ and $\mathrm{CO}_{2}$ contents decrease. This behavior leads to an increase of the LHV of the produced gas with temperature.

The increase of the S/B ratio and temperature also promoted decreasing tar content in the produced gas. This behavior is attributed to steam reforming and thermal reforming of the tars.

The produced gas was mainly composed of $22.8-30.2 \% \mathrm{H}_{2}, 15.1-22.3 \% \mathrm{CO}$, and $7.2-11.1 \% \mathrm{CH}_{4}$, contributing to a heating value of $8.11-9.0 \mathrm{MJ} / \mathrm{Nm}^{3}$.

The performance of the process was assessed in terms of the cold gas and carbon conversion efficiencies. These indicators were found to be in the ranges $47.0-52.1 \%$ and $57.0-62.7 \%$, respectively.

The quality of produced gas obtained from steam gasification and the attained process efficiencies allow beer producers the option to use their own brewing wastes to satisfy their energy needs, moving them toward the circular economy concept.

Further investigations can be carried out to study the effect of BSG deterioration on its chemical and physical characteristics and the impact on the produced gas composition via gasification.

Author Contributions: Conceptualization, S.F. and E.M.; investigation, S.F., C.C. and L.C.; methodology, S.F. and E.M.; resources, C.V. and P.B.; supervision, E.M., P.B. and C.V.; writing-original draft preparation, S.F.; writing-review and editing, E.M., P.B. and C.V.

Funding: This research was funded by FOUNDATION FOR SCIENCE AND TECHNOLOGY (FCT), grant number SFRH/BD/91894/2012.

Conflicts of Interest: The authors declare no conflict of interest.

\section{References}

1. GES. Yearbook. Electricity Consumption. Available online: https://yearbook.enerdata.net/electricity/ electricity-domestic-consumption-data.html (accessed on 10 December 2018).

2. Korhonen, J.; Honkasalo, A.; Seppälä, J. Circular economy: The concept and its limitations. Ecol. Econ. 2018, 143, 37-46. [CrossRef]

3. Mussatto, S.I. Brewer's spent grain: A valuable feedstock for industrial applications. J. Sci. Food Agric. 2014, 94, 1264-1275. [CrossRef]

4. Aliyu, S.; Bala, M. Brewer's spent grain: A review of its potentials and applications. Afr. J. Biotechnol. 2011, 10, 324-331. [CrossRef]

5. Ferreira, S.; Monteiro, E.; Brito, P.; Vilarinho, C. Biomass resources in Portugal: Current status and prospects. Renew. Sust. Energy Rev. 2017, 78, 1221-1235. [CrossRef]

6. Dos Santos Mathias, T.R.; de Mello, P.P.M.; Servulo, E.F.C. Solid wastes in brewing process: A review. J. Brew. Distill. 2014, 5, 1-9. [CrossRef]

7. Huige, N. Brewery by-products and effluents. In Handbook of Brewing, 2nd ed.; Priest, F.G., Stewart, G.G., Eds.; Taylor \& Francis Group: Boca Raton, FL, USA, 2006; pp. 656-707.

8. Stojceska, V.; Ainsworth, P.; Plunkett, A.; Ibanoglu, E.; Ibanoglu, S. Cauliflower by-products as a new source of dietary fibre, antioxidants and proteins in cereal based ready-to-eat expanded snacks. J. Food Eng. 2008, 87, 554-563. [CrossRef] 
9. Faulds, C.B.; Collins, S.; Robertson, J.A.; Treimo, J.; Eijsink, V.G.H.; Hinz, S.W.A.; Schols, H.A.; Buchert, J.; Waldron, K.W. Protease-induced solubilisation of carbohydrates from brewers' spent grain. J. Cereal Sci. 2009, 50, 332-336. [CrossRef]

10. Fillaudeau, L.; Blanpain-Avet, P.; Daufin, G. Water, wastewater and waste management in brewing industries. J. Clean. Prod. 2006, 14, 463-471. [CrossRef]

11. Gupta, M.; Abu-Ghannam, N.; Gallaghar, E. Barley for brewing: Characteristic changes during malting, brewing and applications of its by-products. Compr. Rev. Food Sci. Food Saf. 2010, 9, 318-328. [CrossRef]

12. Reis, S.F.; Gullón, B.; Gullón, P.; Ferreira, S.; Maia, C.J.; Alonso, J.L.; Domingues, F.C.; Abu-Ghannam, N. Evaluation of the prebiotic potential of arabinoxylans from brewer's spent grain. Appl. Microbiol. Biotechnol. 2014, 98, 9365-9373. [CrossRef]

13. Guo, M.; Du, J.; Zhang, Z.A.; Zhang, K.; Jin, Y. Optimization of brewer's spent grain-enriched biscuits processing formula. J. Food Process. Eng. 2014, 37, 122-130. [CrossRef]

14. Russ, W.; Mortel, H.; Meyer-Pittroff, R. Application of spent grains to increase porosity in bricks. Constr. Build. Mater. 2005, 19, 117-126. [CrossRef]

15. Sezun, M.; Grilc, V.; Zupancic, G.D.; Logar, R.M. Anaerobic digestion of brewery spent grain in a semi-continuous bioreactor: Inhibition by phenolic degradation products. Acta Chim. Slov. 2011, 58, 158-166.

16. Bougrier, C.; Dognin, D.; Laroche, C.; Gonzalez, V.; Benali-Raclot, D.; Rivero, J.A.C. Anaerobic digestion of brewery spent grains: Trace elements addition requirement. Bioresour. Technol. 2018, 247, 1193-1196. [CrossRef]

17. Tavasoli, A.; Ahangari, M.G.; Soni, C.; Dalai, A.K. Production of hydrogen and syngas via gasification of the corn and wheat dry distillers grains (DDGS) in a fixed be micro reactor. Fuel Process. Technol. 2009, 90, 472-482. [CrossRef]

18. Micco, G.; Fouga, G.; Bohé, A. Coal gasification studies applied to $\mathrm{H}_{2}$ production. Int. J. Hydrog. Energy 2010, 35, 6012-6018. [CrossRef]

19. Faravelli, T.; Pinciroli, M.; Pisano, F.; Bozzano, G.; Dente, M.; Ranzi, E. Thermal degradation of polystyrene. J. Anal. Appl. Pyrolysis 2001, 60, 103-121. [CrossRef]

20. Grieco, E.; Baldi, G. Pyrolysis of polyethylene mixed with paper and wood: Interaction effects on tar, char and gas yields. Waste Manag. 2012, 32, 833-839. [CrossRef]

21. Zhao, X.; Song, Z.; Liu, H.; Li, Z.; Li, L.; Ma, C. Microwave pyrolysis of corn stalk bale: A promising method for direct utilization of large-sized biomass and syngas production. J. Anal. Appl. Pyrolysis 2010, 89, 87-94. [CrossRef]

22. Marongiu, A.; Faravelli, T.; Bozzano, G.; Dente, M.; Ranzi, E. Thermal degradation of poly (vinyl chloride). J. Anal. Appl. Pyrolysis 2003, 70, 519-553. [CrossRef]

23. Lee, K.; Shin, D. Characteristics of liquid product from the pyrolysis of waste plastic mixture at low and high temperatures: Influence of lapse time of reaction. Waste Manag. 2007, 27, 168-176. [CrossRef]

24. Tamošiūnas, A.; Chouchène, A.; Valatkevičius, P.; Gimžauskaitè, D.; Aikas, M.; Uscila, R.; Ghorbel, M.; Jeguirim, M. The potential of thermal plasma gasification of olive pomace charcoal. Energies 2017, 10, 710. [CrossRef]

25. Favas, J.; Monteiro, E.; Rouboa, A. Hydrogen production using plasma gasification with steam injection. Int. J. Hydrog. Energy 2017, 42, 10997-11005. [CrossRef]

26. Faaij, A.P.C. Bioenergy in Europe: Changing technology choices. Energy Policy 2006, 34, 322-342. [CrossRef]

27. Maniatis, K. Progress in biomass gasification: An overview. In Progress in Thermochemical Biomass Conversion; Bridgwater, A.V., Ed.; Blackwell Science: London, UK, 2001; pp. 1-31.

28. Rupesh, S.; Muraleedharan, C.; Arun, P. A comparative study on gaseous fuel generation capability of biomass materials by thermo-chemical gasification using stoichiometric quasi-steady-state model. Int. J. Energy Environ. Eng. 2015, 6, 375-384. [CrossRef]

29. Hiroyuki, O.Y.K.; Minowa, T.; Ogi, T. Catalytic conversion of high moisture spent grains to a gaseous fuel. Master Brew. Assoc. Am. 1999, 36, 239-241.

30. Mahmood, A.S.N.; Brammer, J.G.; Hornung, A.; Steele, A.; Poulston, S. The intermediate pyrolysis and catalytic steam reforming of Brewers spent grain. J. Anal. Appl. Pyrolysis 2013, 103, 328-342. [CrossRef]

31. Borel, L.D.M.S.; Lira, T.S.; Ribeiro, J.A.; Ataíde, C.H.; Barrozo, M.A.S. Pyrolysis of brewer's spent grain: Kinetic study and products identification. Ind. Crop. Prod. 2018, 121, 388-395. [CrossRef] 
32. Sim, T.S.; Oh, J.C.S. Spent brewery grains as substrate for the production of cellulases by Trichoderma reesei QM9414. J. Ind. Microbiol. 1990, 5, 153-158. [CrossRef]

33. García, R.; Pizarro, C.; Lavín, A.G.; Bueno, J.L. Biomass proximate analysis using thermogravimetry. Bioresour. Technol. 2013, 139, 1-4. [CrossRef]

34. Channiwala, S.A.; Parikh, P.P. A unified correlation for estimating HHV of solid, liquid and gaseous fuels. Fuel 2002, 81, 1051-1063. [CrossRef]

35. Basu, P. Biomass Gasification and Pyrolysis: Practical Design and Theory, 2nd ed.; Elsevier: Oxford, UK, 2013; ISBN 978-0-12-374988-8.

36. Kaewluan, S.; Pipatmanomai, S. Potential of synthesis gas production from rubber wood chip gasification in a bubbling fluidised bed gasifier. Energy Convers. Manag. 2011, 52, 75-84. [CrossRef]

37. Silva, V.; Couto, N.; Monteiro, E.; Rouboa, A. Assessment of municipal solid wastes gasification in a semi-industrial gasifier using syngas quality indices. Energy 2015, 93, 864-873. [CrossRef]

38. Wu, Z.; Rodgers, R.P.; Marshall, A.G. Two- and three-dimensional van Krevelen diagrams: A graphical analysis complementary to the Kendrick mass plot for sorting elemental compositions of complex organic mixtures based on ultrahigh-resolution broadband fourier transform ion cyclotron resonance mass measurements. Anal. Chem. 2004, 76, 2511-2516. [CrossRef]

39. Silva, V.; Monteiro, E.; Couto, N.; Brito, P.S.D.; Rouboa, A. Analysis of syngas quality from Portuguese biomasses: An experimental and numerical study. Energy Fuels 2014, 28, 5766-5777. [CrossRef]

40. Chen, Z.; Hu, M.; Zhu, X.; Guo, D.; Liu, S.; Hu, Z.; Xiao, B.; Wang, J.; Laghari, M. Characteristics and kinetic study on pyrolysis of five lignocellulosic biomass via thermogravimetric analysis. Bioresour. Technol. 2015, 192, 441-450. [CrossRef]

41. Ismail, T.M.; Abd El-Salam, M.; Monteiro, E.; Rouboa, A. Eulerian-Eulerian CFD model on fluidized bed gasifier using coffee husk as fuel. Appl. Therm. Eng. 2016, 106, 1391-1402. [CrossRef]

42. Monteiro, E.; Ismail, T.M.; Ramos, A.; Abd El-Salam, M.; Brito, P.; Rouboa, A. Experimental and modeling studies of Portuguese peach stone gasification on an autothermal bubbling fluidized bed pilot plant. Energy 2018, 142, 862-877. [CrossRef]

43. Monteiro, E.; Ismail, T.M.; Ramos, A.; Abd El-Salam, M.; Brito, P.; Rouboa, A. Assessment of the miscanthus gasification in a semi-industrial gasifier using a CFD model. Appl. Therm. Eng. 2017, 123, 448-457. [CrossRef]

44. Vanreppelen, K.; Vanderheyden, S.; Kuppens, T.; Schreurs, S.; Yperman, J.; Carleer, R. Activated carbon from pyrolysis of brewer's spent grain: Production and adsorption properties. Waste Manag. Res. 2014, 32, 634-645. [CrossRef]

45. Celaya, A.M.; Lade, A.T.; Goldfarb, J.L. Co-combustion of brewer's spent grains and Illinois no. 6 coal: Impact of blend ratio on pyrolysis and oxidation behavior. Fuel Process. Technol. 2015, 129, 39-51. [CrossRef]

46. Nowakowski, D.J.; Jones, J.M.; Brydson, R.M.D.; Ross, A.B. Potassium catalysis in the pyrolysis behaviour of short rotation willow coppice. Fuel 2007, 86, 2389-2402. [CrossRef]

47. Loha, C.; Chatterjee, P.K.; Chattopadhyay, H. Performance of fluidized bed steam gasification of biomass e modeling and experiment. Energy Convers. Manag. 2011, 52, 1583-1588. [CrossRef]

48. Couto, N.; Monteiro, E.; Silva, V.; Rouboa, A. Hydrogen-rich gas from gasification of Portuguese municipal solid wastes. Int. J. Hydrog. Energy 2016, 41, 10619-10630. [CrossRef]

49. Rakesh, N.; Dasappa, S. A critical assessment of tar generated during biomass gasification-Formation, evaluation, issues and mitigation strategies. Renew. Sust. Energy Rev. 2018, 91, 1045-1064. [CrossRef]

(c) 2019 by the authors. Licensee MDPI, Basel, Switzerland. This article is an open access article distributed under the terms and conditions of the Creative Commons Attribution (CC BY) license (http://creativecommons.org/licenses/by/4.0/). 